\title{
PRODUCTIVITY PERFORMANCE IN AGRICULTURE: COMPARISON OF THE BALTIC COUNTRIES
}

\author{
Ieva Leimane, Agnese Krieviṇa, Ligita Melece
}

Institute of Agricultural Resources and Economics; Latvia

ieva.leimane@arei.lv; agnese.krievina@arei.lv; ligita.melece@arei.lv

\begin{abstract}
The productivity and its performance is one of the core topics of economics studies. The growth of productivity is an indicator of competitiveness, as well as a possible way to achieve economic growth and wellbeing. After joining the EU, the agriculture of the Baltic countries faced increasing competition of the EU Single Market, while having relatively lower productivity indicators. Since 2004, significant structural changes have taken place in the agriculture of the Baltic countries, and it is a topical question whether these changes and overall trends in the agricultural sectors of the Baltic countries have facilitated to increase productivity. Therefore, the objective of the study is to evaluate the productivity growth of the main production factors and the total factor productivity growth in the agriculture of the Baltic countries between 2004 and 2015, in relation to the changes in the use of the production factors. The paper focuses on the value added as output, and land, labour and capital as individual inputs to obtain partial productivity measures. The evaluation of TFP is based on the Index number approach, where TFP growth is a ratio of the Output index to the Input index. The calculations and analyses show that since 2004 both the agricultural output and value added have increased in the agriculture of the Baltic countries, and also productivity performance has improved.
\end{abstract}

Key words: production factors, total factor productivity, agriculture, Baltic countries.

\section{Introduction}

In the production process, as a result of human labour and use of machinery and specific technologies, after a certain period of time and consumption of materials the product is generated. If the product is sold in the market, the production costs are covered from the sales revenues, and the generated value added is a source for covering the costs of production factors.

Studies on the future of agricultural farms in Europe occasionally give a definition that a farm is viable if it has at least an income that covers its expenditures (Fritzsch et al., 2011).

After joining the European Union (EU), in 2004 the agriculture of the Baltic countries demonstrated low partial productivity, particularly as to the efficiency in the use of labour (value added at current prices was 2.0 EUR per annual working unit (AWU) in Latvia, EUR 3.1 per AWU in Lithuania and EUR 5.4 per AWU in Estonia, compared to EUR 13.8 per AWU as the EU-27 average). Also, total value added per output unit was notably smaller than the EU average; consequently, the ability of farms in the Baltic countries to pay for production factors was lower. As a result, since 2004 significant changes have taken place in the farm structure in the Baltic countries: the total number of farms has fallen by about $1 / 3$, and, along with an increase in agricultural output, the concentration in contribution to value added and management of production factors has increased too.

As an external factor, after joining the EU Single Market with free movement of goods and production resources the higher competition in agricultural product market as well as in the market of production resources, mainly labour, had an effect on the development of the agricultural sectors in the Baltic countries.

Also, the development of the agricultural sector in all three Baltic countries has been affected by the EU Common Agricultural Policy, where one of the five objectives for its establishing is to increase agricultural productivity by promoting technical progress and by ensuring the rational development of agricultural production and the optimum utilisation of the factors of production, in particular labour (Massot, 2016).

It is a topical question whether these structural changes and overall trends in the agricultural sectors of the Baltic countries have facilitated productivity growth in agriculture. Productivity growth is a desirable outcome of development and technological progress. As productivity not only determines wealth and economic growth as well as is an indicator of competitiveness, it also creates foundations for management decisions both at the firm level and also at the national level for policy makers (Benkkovskis \& Bēms, 2014; Polak, 2017).

The objective of the study is to evaluate the productivity growth of the main production factors and the total factor productivity growth in the agriculture of the Baltic countries between 2004 and 2015, in relation to the changes in the use of the production factors. Therefore, the study analyses the dynamics of the utilisation of agricultural production factors and qualitative structural changes in the Baltic countries by comparing the indicators of 2015 to those of 2004 , as well as calculates and analyses the partial and total factor productivity (TFP) growth in the agriculture of the Baltic countries between 2004 and 2015. 


\section{Materials and Methods}

There are many different productivity measures, and the choice between them depends on the purpose of productivity evaluation and, in many instances, on the availability of data (OECD, 2001). One of the main problems in measuring productivity is the multiple production factors that are used in the production process, as different perspectives could be adopted to form the aggregates resulting in the application of various methods that differ in terms of accuracy, ease of implementation and data requirements (Diewert \& Nakamura, 2002; Csaba, Irz, \& Kuosmanen, 2014). To simplify the problem of aggregation, partial productivity measures are widely used in the economic analysis, which focus only on one output and one input at a time. The main advantage of partial productivity measures is the ease of calculation and interpretation, but they can sometimes provide a misleading indication of overall productivity when considered in isolation from other indicators (Csaba et al., 2014).

In its turn, the TFP measures consider all inputs and outputs used in the production process. The basic definition of the TFP is the rate of transformation of total input into total output and multiple methods which all can be viewed as measures of the TFP growth exist (Diewert \& Nakamura, 2002).

In this study, the partial productivity measures of the main production factors (values at current prices and also at constant 2005 prices to obtain volume changes are used), as well as the TFP growth has been calculated. TFP growth has been measured, based on the Index number approach, where productivity growth is the change in output not explained by the change in input use. Therefore, the TFP growth has been defined as the ratio of the Output index to the Input index (Diewert \& Nakamura, 2002; Kuosmanen \& Sipiläinen, 2004):

$$
\mathrm{TFP}_{t}=\frac{\mathrm{I}_{q, t}}{\mathrm{I}_{i, t}},
$$

where $I_{q}$ represents the growth rate of output and I stands for the growth rate of inputs, and $t$ - time period considered $(t=2004, \ldots, 2015)$. The variable used for the growth rate of output is the volume index of the output of the agricultural 'industry'.

Whereas, $\mathrm{I}_{\mathrm{i}}$ has been aggregated using Fisher input index (Kuosmanen \& Sipiläinen, 2004):

$$
\begin{aligned}
F_{i, t}= & \left(\frac{\left(\frac{m_{t}}{m_{t-1}} x_{m, t-1}+\frac{l_{t}}{l_{t-1}} x_{l, t-1}+\frac{c_{t}}{c_{t-1}} x_{c, t-1}+\frac{r_{t}}{r_{t-1}} x_{r, t-1}\right)}{\left(x_{m, t-1}+x_{l, t-1}+x_{c, t-1}+x_{r, t-1}\right)}\right. \\
& \left.\frac{\left(\frac{m_{t}}{m_{t-1}} x_{m, t}+\frac{l_{t}}{l_{t-1}} x_{l, t}+\frac{c_{t}}{c_{t-1}} x_{c, t}+\frac{r_{t}}{r_{t-1}} x_{r, t}\right)}{\left(x_{m, t}+x_{l, t}+x_{c, t}+x_{r, t}\right)}\right)^{1 / 2},
\end{aligned}
$$

where $\mathrm{m}$ - growth rate of intermediate consumption; 1 - growth rate of labour input; c - growth rate of capital input; $r$ - growth rate of land input; and $x_{m}, x_{1}$, $\mathrm{x}_{\mathrm{c}}, \mathrm{x}_{\mathrm{r}}$ are the weights for intermediate consumption, labour, capital and land respectively; $\mathrm{t}$ - time period considered $(t=2004, \ldots, 2015)$.

The variables used in the calculations of Fisher input index were defined as follows: $m$ - volume index of intermediate consumption; 1 - volume index of agricultural labour input; $\mathrm{c}$ - volume index of fixed capital consumption; $r$ - growth rate of the utilized agricultural area (UAA); $x_{m}$ - value of intermediate consumption; $x_{1}$ - value of compensation of employees (including calculated remuneration for non-salaried labour force); $x_{c}$ - value of fixed capital consumption multiplied by the average deposit interest rate (i.e., capital rental price according to (Groth, GutierrezDomenech, \& Srinivasan, 2004)); $\mathrm{x}_{\mathrm{r}}$ - value of rents (including calculated rents for owned land).

For other various solutions in the process of the study, appropriate qualitative and quantitative research methods have been used: monographic; analysis and synthesis, data grouping, logical and abstractive constructional, etc.

The main data sources for the study are Eurostat data from the Economic Accounts for Agriculture (EAA) and Farm structure survey, and DG Agri data from Farm Accountancy Data Network (FADN), complemented by the data from the national statistical bureaus of the Baltic countries. Different publications and papers, e.g., research papers and the reports of institutions have also been used in the study.

\section{Results and Discussion}

Production factors, being constituent elements of the key questions in economic theory (what, how much and how to produce?), having limited nature and presenting challenges for economic research in evaluation of productivity and distribution of income, continue to be a topical issue. While analysing the use of production factors and the changes in productivity, the authors of this paper keep to the traditional definition of production factors, namely, land, labour, capital and entrepreneurship. When analysing issues of productivity, this definition of production factors nowadays is used also by other researchers, both in Latvia and internationally (Coelli \& Rao, 2005; Petrick \& Kloss, 2013; Banse, Rothe, \& Shutes, 2013).

The production factor land comprises UAA and soil fertility. Labour represents agribusiness employment (both paid and non-paid labour). Capital covers financial resources that are being invested as well as all means of production created and accumulated by humans and used in manufacturing of goods, including information and intellectual 


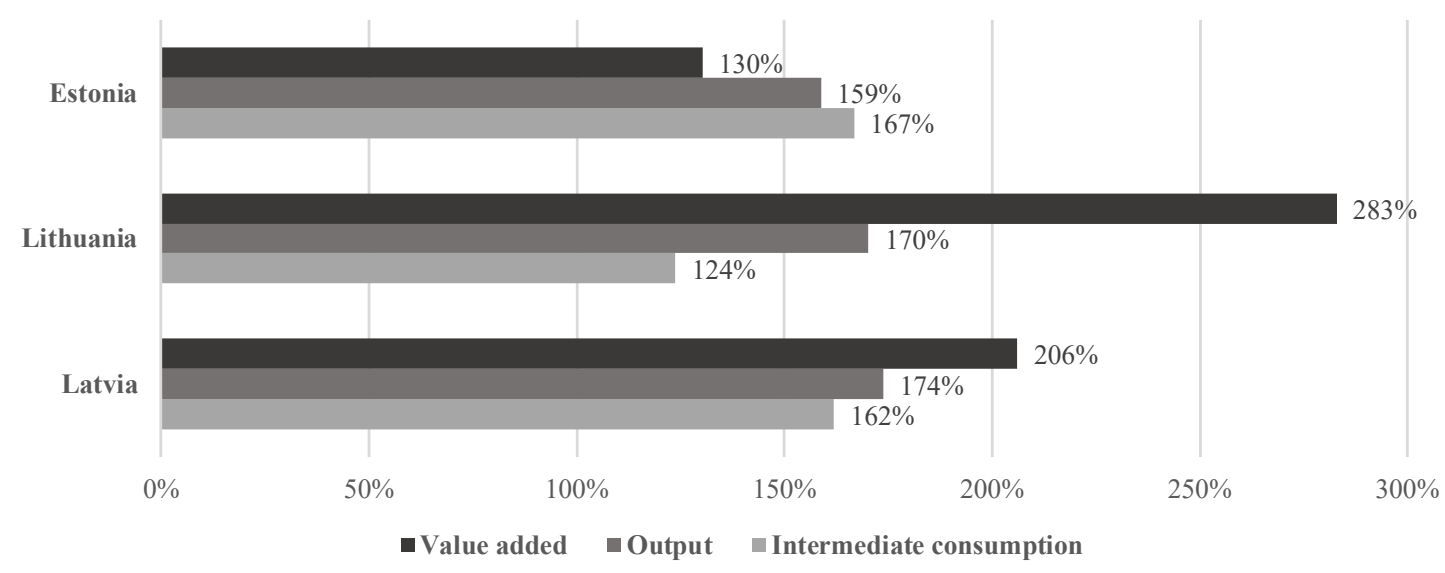

Source: calculations by authors, based on Eurostat (2017a) data.

Figure 1. Development of value added, output and intermediate consumption in the agriculture of Latvia, Lithuania and Estonia in 2015 compared to 2004 (at 2005 constant prices).

capital (patents, licences etc.). In agriculture, contrary to other sectors of economy, biological resources are used in production as well (productive animals and permanent crops), which also fall under this constituent. Entrepreneurship is not being analysed separately: nevertheless, the authors of this paper believe that the productivity of this factor expresses itself in the TFP growth calculations, revealing that part of the TFP growth which cannot be explained with the increase in volume of production factors, i.e., introduction of new technologies, combination of production factors and overall organisation of production (i.e., entrepreneurship as a contributor to the productivity growth).

The utilisation and structure of the production factors In the time period since 2004 (Figure 1), agricultural output in the Baltic countries has increased by about 1.7 times (2015/2004, at 2005 constant prices). Whereas the intermediate consumption (at 2005 constant prices) has increased only by $24 \%$ in Lithuania and by about $60 \%$ in Latvia, and by almost $70 \%$ in Estonia (2015 compared to 2004); therefore, the total increase of value added in agriculture was even more impressive than that of output in Latvia and Lithuania - value added nearly tripled in Lithuania and more than doubled in Latvia, while the growth in Estonia was somewhat slower, by $30 \%(2015 / 2004$, at 2005 constant prices).

There are two ways of increasing output - either by engaging more production factors or, alternatively, by increasing the productivity of utilisation of existing factors (Matthews, 2014). In the period starting from 2004 all Baltic countries have increased the UAA engaged in production. This increase was by $15 \%$ in Latvia and Lithuania and by $25 \%$ in Estonia (Figure 2).
The fact that additional areas of UAA are being engaged in agricultural production points to extensive development. However, the productivity of the use of UAA in all three Baltic countries has increased as well (value added per ha, at 2005 constant prices). When we compare 2015 to 2004 , the productivity of the use of UAA has increased by $145 \%$ in Lithuania, by $80 \%$ in Latvia and by $4 \%$ in Estonia. Thereby, as to the use of UAA, both an increase in production efficiency and expansion were observed.

The structure of the UAA has remained unchanged since 2005 only in Latvia (Table 1) and the extra UAA engaged in agricultural production has been distributed proportionally between the main types of its use.

In 2013, the area of arable land decreased by 5 percentage points in Estonia, while that of permanent grassland and meadow increased, suggesting a more outspoken change in farm specialisation in Estonia in favour of animal farming. Given that in Estonia UAA have increased overall by $25 \%$, of which about $65 \%$ pertain to permanent grassland and meadow, the shift in the specialisation of agricultural production is even more evident. Conversely, in Lithuania the areas of arable land have increased by 13 percentage points while those of permanent grassland and meadow have decreased; therefore, all additionally engaged UAA were diverted to arable land, suggesting of crop farming being selected by Lithuanian farms as their preferred specialisation.

In Latvia and Estonia, the use of fertilisers and other soil improvers (intermediate consumption) for the purpose of increasing soil fertility in 2015 compared to 2004 has increased considerably both in terms of value and volume (Table 2). It is interesting to mention that in Lithuania the productivity of the use of UAA has been achieved without increasing the 

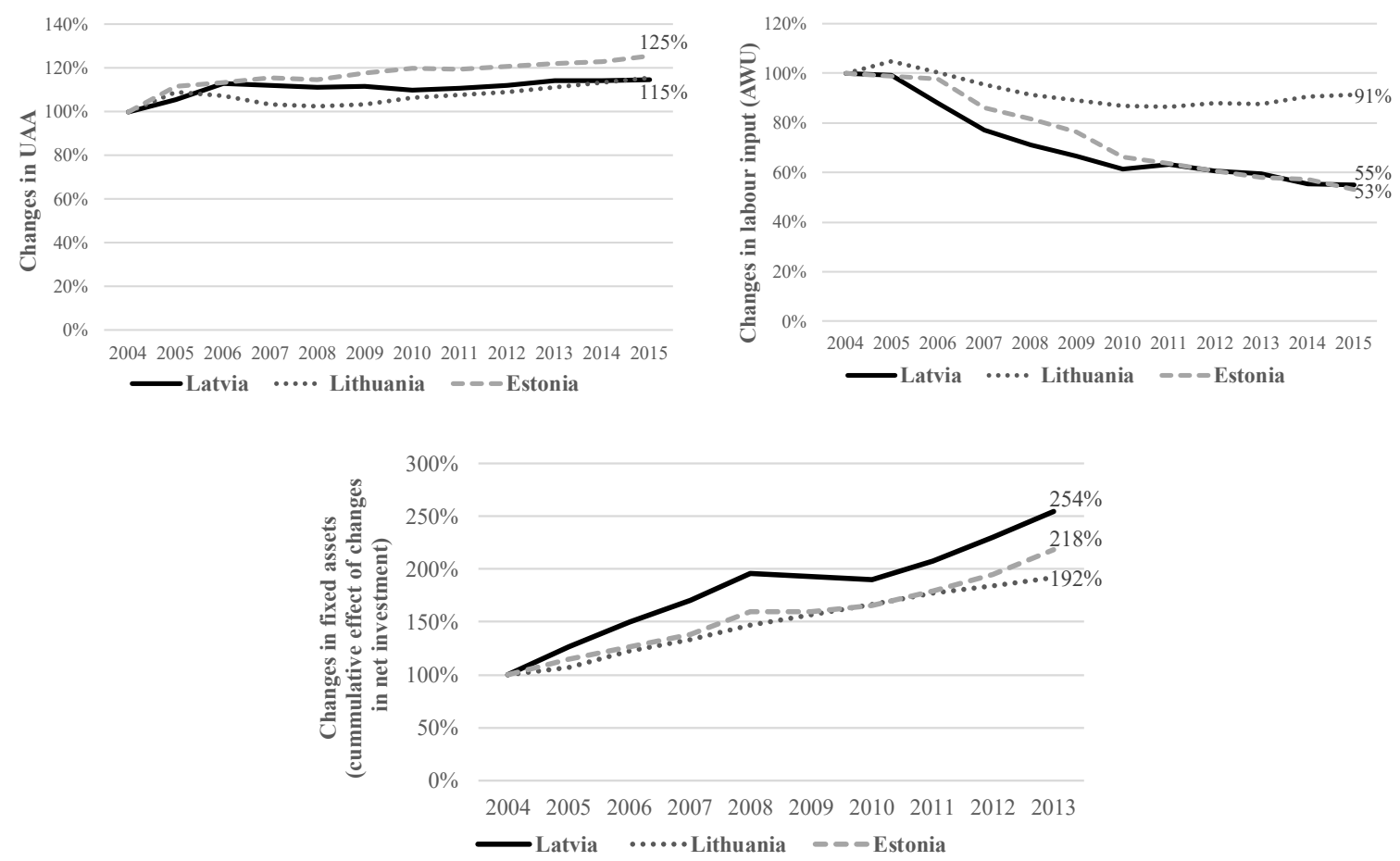

Source: calculations by authors, based on Eurostat (2016), DG Agri FADN (2017), CSB of Latvia (2016c), Statistics Lithuania (2016) and Statistics Estonia (2016) data.

Figure 2. Development of the use of the main production factors in the agriculture of Latvia, Lithuania and Estonia in $2004-2015(2004=100 \%)$.

Use structure of the UAA in Latvia, Lithuania and Estonia in 2005 and 2013

Table 1

\begin{tabular}{|l|c|c|c|c|c|c|}
\hline \multirow{2}{*}{ UAA type } & \multicolumn{3}{|c|}{$\mathbf{2 0 0 5}$} & \multicolumn{3}{c|}{2013} \\
\cline { 2 - 7 } & LV & LT & EE & LV & LT & EE \\
\hline Arable land & $63 \%$ & $67 \%$ & $71 \%$ & $65 \%$ & $79 \%$ & $66 \%$ \\
\hline Permanent crops & $2 \%$ & $1 \%$ & $0 \%$ & $0 \%$ & $1 \%$ & $0 \%$ \\
\hline Permanent grassland and meadow & $35 \%$ & $32 \%$ & $29 \%$ & $35 \%$ & $20 \%$ & $34 \%$ \\
\hline
\end{tabular}

Source: calculation by authors, based on Eurostat (2017b) data.

consumption of fertilisers and other soil improvers per 1 ha of UAA.

At the beginning of the analysed period the proportion of agribusiness employment in overall employment structure was high in the Baltic countries, while average remuneration was low in comparison to the EU average level. In Latvia, a study on the potential development scenarios of rural areas arrived at a conclusion that at the EU average productivity level, even the full utilization of agricultural potential cannot stop the decrease in agribusiness employment in Latvia due to high labour density in Latvian agribusiness (Leimane, Krievina, \& Miglavs, 2011). According to statistics, the labour input in Latvian agriculture has decreased by about half since 2004 (Figure 2). The situation is similar in Estonia, where labour input in 2015 was also about half of the level in 2004, while the decrease in Lithuania was relatively small, by $9 \%$.

With a shrinking labour input and growing value added, an increase in labour productivity has been recorded in the agriculture of the Baltic countries when comparing 2015 to 2004: in Latvia, value added per AWU has increased by 3.8 times, in Lithuania by 3.1 times and in Estonia by 2.5 times (at 2005 constant prices). Despite of that, at the end of the period in Estonia value added per AWU is considerably higher than in Lithuania and Latvia - EUR 13.7 per AWU, EUR 7.4 per AWU and EUR 4.8 per AWU respectively; thus, in absolute terms, Estonia has demonstrated a higher growth of productivity in agribusiness employment since 2004. 
Use of fertilisers and soil improvers in Latvia, Lithuania and Estonia in 2004 and 2015

\begin{tabular}{|l|c|c|c|c|c|c|}
\hline \multirow{2}{*}{} & \multicolumn{3}{|c|}{ Values at current prices } & \multicolumn{2}{c|}{ Values at constant prices (2005) } \\
\cline { 2 - 7 } & \multicolumn{2}{|c|}{ EUR ha $^{-\mathbf{1}}$} & $\mathbf{2}$ & \multicolumn{2}{c|}{ EUR ha $^{-1}$} & \% \\
\cline { 2 - 7 } & $\mathbf{2 0 0 4}$ & $\mathbf{2 0 1 5}$ & $\mathbf{2 0 1 5 / 2 0 0 4}$ & $\mathbf{2 0 0 4}$ & $\mathbf{2 0 1 5}$ & $\mathbf{2 0 1 5 / 2 0 0 4}$ \\
\hline Latvia & 20.3 & 75.3 & $371 \%$ & 24.5 & 39.9 & $163 \%$ \\
\hline Lithuania & 45.5 & 100.4 & $221 \%$ & 56.5 & 55.9 & $99 \%$ \\
\hline Estonia & 16.5 & 57.9 & $352 \%$ & 17.4 & 42.4 & $244 \%$ \\
\hline
\end{tabular}

Source: calculation by authors, based on Eurostat (2017a) data.

Table 3

Farm managers by their agricultural education in Latvia, Lithuania and Estonia in $2005-2013, \%$ of total number of farms

\begin{tabular}{|l|c|c|c|c|c|c|}
\hline & \multicolumn{3}{|c|}{2005} & \multicolumn{3}{c|}{2013} \\
\cline { 2 - 7 } & $\begin{array}{c}\text { Practical } \\
\text { experience only }\end{array}$ & $\begin{array}{c}\text { Basic } \\
\text { training }\end{array}$ & $\begin{array}{c}\text { Full agricultural } \\
\text { training }\end{array}$ & $\begin{array}{c}\text { Practical } \\
\text { experience only }\end{array}$ & $\begin{array}{c}\text { Basic } \\
\text { training }\end{array}$ & $\begin{array}{c}\text { Full agricultural } \\
\text { training }\end{array}$ \\
\hline Latvia & $66 \%$ & $12 \%$ & $22 \%$ & $58 \%$ & $13 \%$ & $28 \%$ \\
\hline Lithuania & $69 \%$ & $19 \%$ & $12 \%$ & $65 \%$ & $19 \%$ & $15 \%$ \\
\hline Estonia & $67 \%$ & $11 \%$ & $22 \%$ & $60 \%$ & $14 \%$ & $26 \%$ \\
\hline
\end{tabular}

Source: calculation by authors, based on Eurostat (2017a) data.

Since 2004, in the Baltic countries the qualifications of those engaged in agriculture have become more advanced. The analysis of education and hands-on experience of farm managers leads to a conclusion that in all three Baltic countries the share of farm managers having obtained full agricultural training has increased (by 3 percentage points in Lithuania and by 6 percentage points in Latvia), with a concurrent decrease of the share of farm managers having only practical agricultural experience and skills (Table 3 ).

In the course of production process, production factors form a reciprocal structure and interact in a technologically organised manner. An analysis of interconnection between the dynamics of labour input and capital investment allows concluding that against the background of increased output, a fall in labour input in the agriculture of the Baltic countries has been possible on account of its substitution with capital (Figure 2). Starting from 2004, significant investments towards development of fixed assets have been made in the agricultural sectors of the Baltic countries. According to generalised FADN farm group data, total net investment amount in 20051013 was EUR 2,555 million in Lithuania, EUR 1,366 million in Latvia and EUR 872 million in Estonia. In Lithuania, this equals EUR 960 per ha of agricultural land in these farms in 2013, in Latvia EUR 870 per ha and in Estonia EUR 840 per ha. As an effect of net investment, the highest resulting increase in the value of fixed assets is observed in Latvia (by 2.5 times), followed by Estonia (by 2.2 times) and Lithuania (by 1.9 times).

As a result of long-term investment, the structure of fixed assets in Latvia has not undergone any major changes in 2013, investment in land contributed 35\% of total value of fixed assets, while the contribution of investment in buildings was $26 \%$, that of technological machinery and equipment was $31 \%$ and that of productive animals was $7 \%$. As to Lithuania, in 2013 compared to 2004 there has been a 15 percentage point increase in the share of technological equipment in terms of value, amounting to $46 \%$; investment in land being $32 \%$ and investment in buildings being $15 \%$ of total value of fixed assets. As to Estonia, in 2013 investment in technological machinery and equipment dominated in the structure of fixed assets - 36\% (an increase by 13 percentage points compared to 2004), while investment in land contributed $25 \%$, investment in buildings $31 \%$ and investment in productive animals $8 \%$ to total value of fixed assets.

\section{Evaluation of the total factor productivity growth}

TFP growth reflects the part in production efficiency growth that is not due to the increase in the volume of factors invested in production. Thereby the TFP growth is a result of combined effect of multiple elements associated with production management and organisation (entrepreneurship), as well as the implementation of new technologies, management skills, changes in production organisation, and economy of scale. 


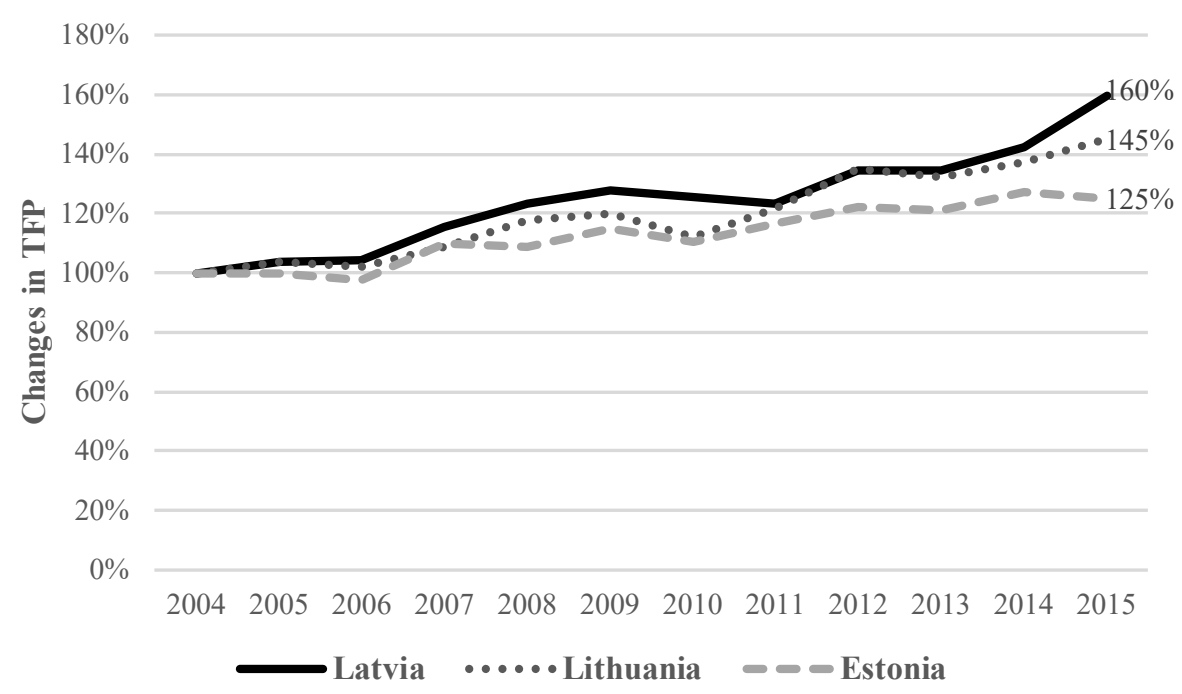

Source: calculations by authors, based on Eurostat (2017a; 2016), CSB of Latvia (2016a; 2016c), Statistics Lithuania (2016a; 2016b), Statistics Estonia (2016); DG Agri FADN (2017) data.

Figure 3. Development of the total factor productivity growth in the agriculture of Latvia, Lithuania and Estonia in $2004-2015(2004=100 \%)$.

The calculations performed by applying the Index number approach evidence that between 2004 and 2015 the fastest TFP growth by $60 \%$ has been observed in the Latvian agriculture. (Figure 3).

The analysis of the TFP growth in combination with the dynamics of the utilisation of production factors and the changes in the partial productivity performance of the factors concerned leads to a conclusion that, as to Latvia, the ability to productively use investments in the development of capital was the driver of a faster TFP growth, enabling a rise in labour and UAA utilisation productivity and restricting the increase of intermediate consumption, which, as a result, was slower than that of agricultural output (Figure 1). The qualification of farm managers, too, is relatively higher in Latvia than in the rest of the Baltic countries.

Also in Lithuania, a growing productivity of UAA has largely facilitated the TFP increase (by 45\%), including structural changes and a higher share of arable land, as well as investment in capital and production organisation, which enabled to raise the labour productivity and also to curtail the growth of intermediate consumption relative to output.

Contrary to other Baltic countries, in absolute terms, Estonia already at the beginning of the period demonstrated a higher productivity both in the utilisation of labour and UAA. Thus, a relatively slower TFP growth (by 25\%) does not speak of inferior performance in absolute terms: in 2015 labour productivity (value added in EUR per AWU) in Estonia was by $84 \%$ higher than in Lithuania and almost 3 times as much as in Latvia. In the period since 2014, the TFP growth in Estonia was facilitated by the ability to combine investment in capital, thereby achieving an increase in labour productivity; conversely, an increase in intermediate consumption, which was higher than that of output (Figure 1), slowed down the TFP growth.

Despite the fact that the TFP growth in Latvia was faster over the analysed period, value added per full-time employee is the lowest among the Baltic countries, and this continues to determine the relatively low average remuneration in the sector.

\section{Conclusions}

1. Since 2004, both the agricultural output and value added have increased in the agriculture of the Baltic countries, and also productivity performance has improved.

2. The UAA engaged in production has increased in all Baltic countries, especially in Estonia. Along with the expansive development direction which enabled a growth in agricultural output, the productivity of UAA (value added per ha, in constant prices) has also increased in all Baltic countries. Lithuania has demonstrated the highest growth of the productivity of UAA (2015 compared to 2004); moreover, it has been achieved without an increase in the consumption of fertilisers and other soil improvers per hectare of UAA. However, it should be mentioned that structural changes in the use of UAA point to a shift in specialisation in Lithuania, where preference is given to crop farming, while animal farming is more favoured in Estonia, but in Latvia 
the structure of the use of UAA has not changed significantly.

3. Starting from 2004, labour input in agriculture has been decreasing: in Latvia and Estonia labour input in 2015 was about one half of the 2004 level, while the decrease in Lithuania was relatively small. With a simultaneous investment in the growth of fixed assets and upgrades in the farm machinery and equipment, all three Baltic countries have been able to achieve higher labour productivity: in Latvia, value added per full time employee has increased by 3.8 times, in Lithuania by 3.1 times and in Estonia by 2.5 times (at constant prices).

4. The TFP growth dynamics between 2004 and 2015 has been similar in the Baltic countries. Agriculture in Latvia reports the most rapid cumulative TFP growth. This was fostered by an ability to efficiently use investments for development of capital, allowing an increased productivity in the use of labour and UAA, and restrict the increase of intermediate consumption, which, as a result, was lower than that of agricultural output. In Lithuania, the TFP increase is the result of a growing UAA productivity, including structural changes in the use of UAA, as well as investment in capital and production organisation, which enabled to curtail the growth of intermediate consumption and also to raise the labour productivity relative to output. The TFP growth in Estonia was relatively slower; it was facilitated by the ability to combine investment in capital, thereby achieving an increase in labour productivity, however, an increase in intermediate consumption, which was higher than that of output slowed down the TFP growth. Contrary to other Baltic countries, in absolute terms, Estonia already at the beginning of the period demonstrated a higher productivity both in the utilisation of labour and UAA. Thus, a relatively slower TFP growth does not speak of inferior performance in absolute terms.

5. Despite the fact that Latvia demonstrated the fastest TFP growth after the EU accession, value added per full-time employee is nevertheless the lowest among the Baltic countries, and this continues to determine the relatively low average remuneration in the sector and has a negative effect on the competitiveness of the sector.

\section{Acknowledgements}

The paper was supported by the National Research Programme 5.2.1. SUSTINNO.

\section{References}

1. Beṇkovskis, K., \& Bēms, R. (2014). Latvijas konkurētspēja un produktivitāte: kas tālāk? (Latvian competitiveness and productivity: what's next?). Retrieved January 25, 2016, from: http://www.slideshare. net/LatvijasBanka/latvijas-konkurtspja-un-produktivitte-kas-tlk (in Latvian).

2. Central Statistics Bureau of Latvia (CSB) (2015). Agricultural training of managers by statistical regions. Retrieved January 18, 2017, from: http://data.csb.gov.lv/pxweb/en/lauks/lauks_ _ikgad_laukstrukt_13_1. visp/LSS13 I05.px/?rxid=cdcb978c-22b0-416a-aacc-aa650d3e2ce0.

3. Central Statistics Bureau of Latvia (CSB) (2016c). Use of agricultural area. Retrieved January 8, 2017, from: http://data.csb.gov.lv/pxweb/en/lauks/lauks_ikgad_01Lauks_visp/?tablelist=true\&rxid=a79839 fe-11ba-4ecd-8cc3-4035692c5fc8.

4. Central Statistics Bureau of Latvia (CSB). (2016a). Average weighted interest rates on deposits in credit institutions. Retrieved January 10, 2017, from: http://data.csb.gov.lv/pxweb/en/arhivs/arhivs_ ikgad banku/BR0010.px/?rxid=cdcb978c-22b0-416a-aacc-aa650d3e2ce0.

5. Central Statistics Bureau of Latvia (CSB). (2016b). Farm structure survey - survey 2003, $2005,2007$. Managers by Gender, Agricultural Education and Region. Retrieved January 17, 2017, from: http://data. csb.gov.lv/pxweb/en/lauks/lauks_ikgad_laukstrukt/006_vad_izgl_LV.px/?rxid=cdcb978c-22b0-416aaacc-aa650d $3 \mathrm{e} 2 \mathrm{ce} 0$.

6. Csaba, J., Irz, X., \& Kuosmanen, N. (2014). Competitiveness of Northern European dairy chains. Finland: MTT Economic Research, Agrifood Reacher Finland.

7. DG Agri. (2017). FADN public database. Retrieved January 18, 2017, from: http://ec.europa.eu/agriculture/ rica/database/database_en.cfm.

8. Diewert, W.E., \& Nakamura, A.O. (2002). The measurement of aggregate total factor productivity growth. Retrieved December 10, 2016, from: http://economics.ubc.ca/files/2013/06/pdf_paper_erwin-diewert-0205-measurement-aggregate.pdf.

9. Eurostat (2016). Agricultural labour input statistics. Retrieved January 9, 2017, from: http://appsso. eurostat.ec.europa.eu/nui/show.do?dataset=aact_ali01\&lang=en.

10. Eurostat (2017a). Economic Accounts for Agriculture. Retrieved January 11, 2017, from: http://appsso. eurostat.ec.europa.eu/nui/show.do?dataset=ef_oluft\&lang=en. 
11. Eurostat (2017b). Farm structure. Overview - farm land use. Retrieved January 15, 2017, from: http:// ec.europa.eu/eurostat/data/database.

12. Fritzsch, J., Wegener, S., Buchenrieder, G., Curtiss, J., \& Paloma, S.G. (2011). Is there a future for semisubsistence farm households in Central and southeastern Europe? A multiobjective linear programming approach. Journal of Policy Modeling. 33, 70 - 91. DOI: 10.1016/j.jpolmod.2010.10.005.

13. Groth, C., Gutierrez-Domenech, M., \& Srinivasan, S. (2004). Measuring total factor productivity for the United Kingdom. Retrieved December 10, 2016, from: http:/www.bankofengland.co.uk/publications/ Documents/quarterlybulletin/qb040106.pdf.

14. Kuosmanen, T., \& Sipiläinen, T. (2004). On the anatomy of productivity growth: a decomposition of the Fisher Ideal TFP Index. Retrieved December 8, 2016, from: https://jukuri.luke.fi/bitstream/ handle/10024/481591/DP2004_17.pdf?sequence=1.

15. Leimane, I., Krievina, A., \& Miglavs, A. (2014). Improving of Small Farm Market Capability in Latvia. Procedia - Social and Behavioral Sciences, 110, 182 - 189. DOI: 10.1016/j.sbspro.2013.12.861.

16. Massot, A. (2016). The Common Agricultural Policy (CAP) and The Treaty. Retrieved March 9, 2017 , from: http://www.europarl.europa.eu/atyourservice/lv/displayFtu.html?ftuId=FTU_5.2.1.html.

17. Matthews, A. (2014). What is happening to EU agricultural productivity growth? Retrieved March 7 , 2017, from: http://capreform.eu/what-is-happening-to-eu-agricultural-productivity-growth/.

18. Polak, P. (2017). The productivity paradox: A meta-analysis. Information Economics and Policy. 38,38 54. DOI: 10.1016/j.infoecopol.2016.11.003.

19. Statistics Estonia. (2016). Utilised agricultural land by county. Retrieved January 8, 2017, from: http:// pub.stat.ee/pxweb.2001/I_Databas/Economy/01Agriculture/02Agricultural_production/02Crop_ production/02Crop_production.asp.

20. Statistics Lithuania (2016). Utilised agricultural area used by agricultural producers. Retrieved January 8 , 2017, from: http://osp.stat.gov.lt/en/statistiniu-rodikliu-analize?id=2865\&status=A.

21. The Organisation for Economic Co-operation and Development (OECD). (2001). Measuring productivity. Measurement of aggregate and industry-level productivity growth. Retrieved January 27, 2017, from: http://www.oecd.org/std/productivity-stats/2352458.pdf.

22. Coelli, T.J., \& Rao, D.S.P. (2005). Total Factor Productivity Growth in Agriculture: A Malmquist Index Analysis of 93 Countries, 1980 - 2000. Agricultural Economics, 32(s1), 115 - 134.

23. Petrick, M., \& Kloss, M. (2013). Factor Market Imperfections and Productivity in EU Agriculture. In J. Swinnen \& L. Knops (Eds.), Land, Labour and Capital Markets in European Agriculture. Diversity under a Common Policy (pp. 316 - 333). Brussels: Centre for European Policy Studies.

24. Banse, M., Rothe, A., \& Shutes, L. (2013). Factor Markets in Applied CGE Models. In J. Swinnen \& L. Knops (Eds.), Land, Labour and Capital Markets in European Agriculture. Diversity under a Common Policy (pp. 311 - 315). Brussels: Centre for European Policy Studies. 